\title{
Abundance and Taxonomic Diversity of Bacteria Inhabiting the Sediment- Water Interface in a Marine Harbor Channel
}

\author{
Piotr Perliński*, Zbigniew J. Mudryk, and Marta Zdanowicz \\ Department of Experimental Biology, Pomeranian University in Stupsk, Stupsk 76-200, Poland
}

Received 22 September 2018; Revised 28 January 2019; Accepted 25 March 2019

(c) The Author(s) 2019

\begin{abstract}
The abundance of bacteria inhabiting the sedimentwater interface and their taxonomic composition were determined with the fluorescence in situ hybridization (FISH) method in a marine harbor channel in Ustka. Among bacteria inhabiting the studied layer Gammaproteobacteria $\left(1.4\right.$ cells $\left.10^{8} \cdot \mathrm{dm}^{-3}\right)$ and Cytophaga-Flavobacterium ( 1.1 cells $10^{8} \cdot \mathrm{dm}^{-3}$ ) dominated. Vibrio and Pseudomonas represented only a small fraction of the total cell counts. All taxonomic groups of studied bacteria show significant positive correlation between their abundance. The total bacterial number varied from 3.3 to 23.5 cells $10^{8} \cdot \mathrm{dm}^{-3}$ and their biomass oscillated from 39.4 to $282.4 \mu \mathrm{g} \mathrm{C} \cdot \mathrm{dm}^{-3}$. This parameter differed along horizontal profiles, while there were no significant differences in the abundance of the studied taxonomic groups among the study sites of the channel in Ustka. The total number of bacteria as well as the abundance of bacterial phylogenetic groups were subject to seasonal fluctuation in the studied water basin.
\end{abstract}

Keywords - abundance, bacteria, marine harbor channel, sedimentwater interface, taxonomic diversity

\section{Introduction}

The sediment-water interface (SWI) is an environmental and ecological boundary layer between overlying water and sediment in all water basins (Christian and Lind 2007; Chai et al. 2016). In natural waters, the sediment-water interface is the site where gradients of physical, chemical and biological properties are the greatest (Santschi et al. 1990; Accornero et al. 2002).In natural waters, the sediment-water interface is the site where gradients in physical, chemical and biological properties are the greatest.In natural waters, the sedimentwater interface is the site where gradients in physical, chemical

\footnotetext{
*Corresponding author. E-mail: piotr.perlinski@apsl.edu.pl
}

and biological properties are the greatestIn natural waters, the sediment-water interface is the site where gradients in physical, chemical and biological properties are the greatest SWI is a bio-reactive biotope, which plays a key role in biogeochemical reactions, such as the flux of detrital materials carried through the water column and their incorporation within the sediment record (Wu et al. 2001). These reactions include such processes as dissolution, degradation, mineralization and demineralization, deposition, sorption and desorption, migration, transformation, oxidation and reduction, and enzymatic hydrolysis (Christian and Lind 2007; Zhu et al. 2016). All these processes may strongly influence both water quality and the biota inhabiting SWI (Viaroli et al. 2004). Therefore the sediment-water interface is an important site where cycling of elements between sediments and overlying water is regulated and controlled (Zhu et al. 2016). In SWI large quantities of organic matter delivered from the water column and sediment are accumulated (Queiroz et al. 2004). The main stream of organic matter accumulated in the sediment-water interface originates from photosynthetically produced phytoplankton and microphytobenthos as well as dead phyto- and zooplankton and different anthropogenic pollutions (Bhaskar and Bhosle 2008; Divya et al. 2010). High concentration of organic matter in SWI stimulates optimal conditions for the development of many organisms such as microorganisms, phytoplankton, phytobenthos, macroalgae, vascular plants, meiofauna and macrofauna taxa (Daumas 1990; Snelgrove et al. 2000). Among organisms inhabiting the sediment-water interface the most numerous and those with high productivity and enzymatic activity are microorganisms, mainly aerobic and anaerobic bacteria with different metabolic potential (Xia et al. 2014; Wei et al. 2016). These prokaryotic 
organisms play a key role in ecological functions and processes such as regulation, assimilation, accumulation, export, decomposition, degradation, enzymatic hydrolysis, re-mineralization and transformation of the largest part of organic matter accumulated in SWI (Bucci et al. 2014; Wei et al. 2016). According to Tanase et al. (2009) and Liu et al. (2012), in order to fully understand the role of bacteria in the functioning of the sediment-water interface, it is necessary not only to determine their secondary production, enzymatic activity, respiration processes, morphological differentiation and physiological properties but also to determine their abundance and taxonomic diversity. The role of bacterial population in the functioning of SWI was studied by early researchers including Christian and Lind (2007), Ivanov et al. (2013), Dann et al. (2014), and Chai et al. (2016). However, to our knowledge, no studies are available on the taxonomic structure of bacteria inhabiting the sediment-water interface, in particular a specific water reservoir such as a marine harbour channel. Therefore, the main objective of this study was to determine phylogenetic diversity of bacteria and their abundance in SWI in the marine harbour in Ustka along a horizontal water profile and during different seasons using the fluorescence in situ hybridization (FISH) technique. This technique allows for the gradual revealing, identification and quantifying of different bacterial groups and also the description of the spatio-temporal dynamics of bacterial community structure in a variety of freshwater and marine ecosystems (Alonso et al. 2010; Lefort and Gasol 2013).

\section{Material and Methods}

\section{Study area and site description}

This study was carried out in a marine harbour channel that is the estuarine part of the Stupia River (Poland). The studied channel is $40.5 \mathrm{~m}$ wide and about $6 \mathrm{~m}$ deep, and is located in the vicinity of the port in Ustka $\left(54^{\circ} 35.2 \mathrm{~N}\right.$, $16^{\circ} 21.2 \mathrm{E}$ ) (Fig. 1). The port in Ustka covers an area of 29.3 ha and its main functions are fishery, transport and marine tourism (Christowa et al. 2007). The studied harbour is limited by two breakwaters of about $300 \mathrm{~m}$ in length from the Baltic Sea. Selected chemical and bacteriological parameters of the sediment-water interface in the channel are presented in Table 1, and a detailed method of description regarding their determination is given by Perliński (2015).

The sediment-water interface samples planned for further bacteriological analyses were collected from the marine harbour channel at four sites (Fig. 2).

Site 1 - located on the border between the Słupia River and the studied channel (freshwater zone),

Site 2 - situated in the central part of the channel (brackish water zone),

Site 3 - located in one of the water basins called the coal basin (brackish water zone),

Site 4 - situated at the site where the channel enters the sea, i.e., near the heads of breakwaters (marine zone).
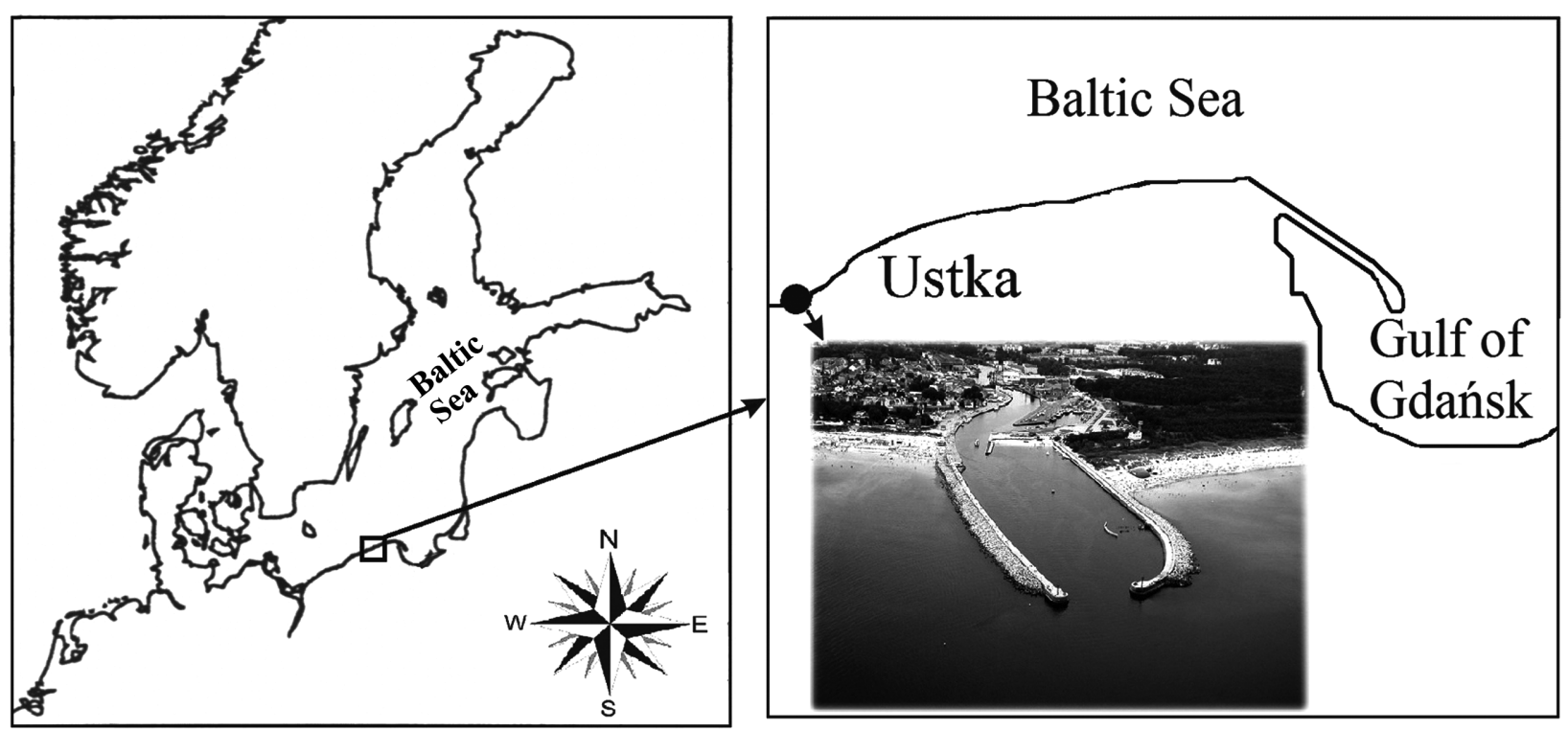

Fig. 1. Map of localization the study marine harbour channel in Ustka 
Table 1. Values of selected chemical and microbiological parameters in sediment-water interface in the harbour channel in Ustka (Perliński 2015)

\begin{tabular}{|c|c|c|c|c|c|c|c|c|}
\hline & \multicolumn{2}{|r|}{ st. 1} & \multicolumn{2}{|r|}{ st. 2} & \multicolumn{2}{|r|}{ st. 3} & \multicolumn{2}{|r|}{ st. 4} \\
\hline Parameters & Mean & Range & Mean & Range & Mean & Range & Mean & Range \\
\hline $\mathrm{N}-\mathrm{NO}_{3}\left(\mathrm{mg} \cdot \mathrm{dm}^{-3}\right)$ & 46.0 & $27.5-68.8$ & 43.2 & $18.3-86.3$ & 45.1 & $24.6-96.6$ & 44.2 & $19.2-101.9$ \\
\hline $\mathrm{N}-\mathrm{NH}_{4}\left(\mathrm{mg} \cdot \mathrm{dm}^{-3}\right)$ & 8.7 & $3.5-14.9$ & 12.3 & $8.6-15.5$ & 14.6 & $8.9-25.4$ & 20.9 & $10.1-47.4$ \\
\hline $\mathrm{Cl}^{-}\left(\mathrm{mg} \cdot \mathrm{dm}^{-3}\right)$ & 396.8 & $48.5-751.9$ & 5774.1 & $4828.7-6822.2$ & 2590.3 & $398.9-5944.2$ & 6009.0 & $5393.5-7386.6$ \\
\hline $\mathrm{O}_{2}\left(\mathrm{mg} \cdot \mathrm{dm}^{-3}\right)$ & 7.7 & $6.6-10.9$ & 7.7 & $3.6-1.5$ & 7.6 & $5.2-9.8$ & 7.8 & $5.4-9.8$ \\
\hline $\mathrm{pH}$ & 7.3 & $7.0-7.5$ & 7.3 & $6.9-7.6$ & 7.3 & $7.0-7.5$ & 7.5 & $7.4-7.6$ \\
\hline Organic Matter $\left(\mathrm{mg} \cdot \mathrm{dm}^{-3}\right)$ & 0.2 & $0.1-0.3$ & 2.4 & $1.7-3.1$ & 0.8 & $0.3-1.1$ & 3.0 & $2.1-3.9$ \\
\hline Protein $\left(\mu \mathrm{g} \cdot \mathrm{dm}^{-3}\right)$ & 21.7 & $15.4-29.8$ & 20.3 & $16.5-24.2$ & 21.9 & $16.9-26.9$ & 24.9 & $18.5-31.9$ \\
\hline Lipids $\left(\mu \mathrm{g} \cdot \mathrm{dm}^{-3}\right)$ & 111.7 & $26.2-238.9$ & 183.0 & $106.5-330.5$ & 76.3 & $32.9-129.3$ & 386.6 & $197.8-624.9$ \\
\hline Carbohydrates $\left(\mu \mathrm{g} \cdot \mathrm{dm}^{-3}\right)$ & 73.1 & $29.8-113.3$ & 79.4 & $21.7-128.8$ & 60.3 & $43.1-94.3$ & 56.6 & $21.8-97.6$ \\
\hline $\begin{array}{l}\text { Number of heterotrophic bacteria } \\
\left(\text { CFU } 10^{6} \cdot \mathrm{dm}^{-3}\right)\end{array}$ & 23.4 & $3.2-91.7$ & 23.4 & $2.3-79.2$ & 24.5 & $4.0-79.2$ & 19.2 & $1.5-62.7$ \\
\hline Bacterial production $\left(\mu \mathrm{g} \mathrm{C} \cdot \mathrm{dm}^{-3} \cdot \mathrm{h}^{-1}\right)$ & 90.4 & $11.3-220.7$ & 50.9 & $4.4-170.7$ & 63.7 & $8.7-181.9$ & 24.4 & $7.1-80.3$ \\
\hline
\end{tabular}

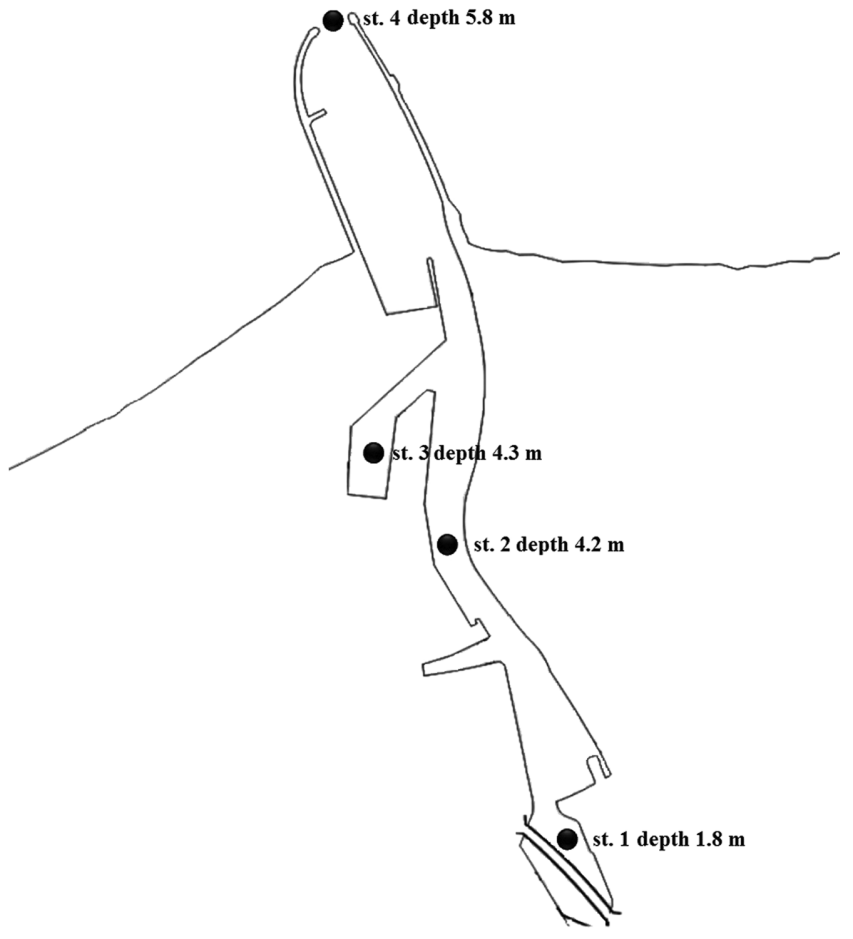

Fig. 2. Location of the sampling sites

\section{Sediment-water interface sampling}

The precise location of each sampling site was taken with a GPS receiver installed on board a tugboat. The water samples were collected during autumn (A) in 2012 and winter (W), spring (SP) and summer (S) in 2013. After localization of the site with an echosounder, the sediment-water interface samples were collected with a horizontal van Dorn water sampler adapted for the collection of the samples in flowing water (Christian and Lind 2007; Ivanov et al. 2013). Prior to sampling, the sampler was rinsed with distilled sterile water and ethyl alcohol. The collected water samples were transferred to sterile glass containers using a drain valve. Then the samples were transported to the laboratory in ice containers at a temperature that did not exceed $7^{\circ} \mathrm{C}$. The time between the collection of the samples and bacteriological analyses usually did not exceed 3 hours.

\section{Determination of phylogenetic groups of bacteria inhabiting} the sediment-water interface and their abundance

It has been well-documented (Cottrell and Kirchman 2000; Franklin et al. 2005; Hervas and Casamayor 2008; Stolle et al. 2011) that the most frequently studied taxonomic groups of bacteria inhabiting the marine coastal zone are such taxa as Cytophaga-Flavobacterium, Gammaproteobacteria, Marine alpha-cluster, Pseudomonas and Vibrio. Therefore, in the present study we also focused on phylogenetic analyses of these taxonomic groups. Bacterial phylogenetic groups and their cell abundance in the sediment-water interface of the studied channel were determined by the fluorescence in situ hybridization (FISH) technique using fluorescence-labelled, rRNA targeted oligonucleotide probes. The probe sequences, hybridization conditions and references used in this study are given in Table 2. For the determination of selected phylogenetic groups of bacteria, $20 \mathrm{~cm}^{3}$ of each water sample was fixed with formaldehyde (final concentration 4\%) and filtered through white polycarbonate filters with a diameter of $47 \mathrm{~mm}$ and a pore size of $0.2 \mu \mathrm{m}$. The filters were removed from the filtration apparatus, rinsed with sterile distilled water, air 
Table 2. The probes used in FISH

\begin{tabular}{cccc}
\hline \hline Oligonucleotide probe & Polygenetic target & Probe sequence & Reference \\
\hline EUB338 & Bacteria & 5'-GCTGCCTCCCGTAGGAGT-3' & Amman et al. (1990) \\
CF319a & Cytophaga-Flavobacterium & 5'-TGGTCCGTGTCTCAGTAC-3' & Manz et al. (1996) \\
GAM42a & Gammaproteobacteria & 5'-GCCTTCCCACATCGTTT-3' & Manz et al. (1992) \\
ROS537 & Marine alpha-cluster & 5'-CAACGCTAACCCCCTCC-3' & Eilers et al. (2001) \\
PAE997 & Pseudomonas & 5'-TCTGGAAAGTTCTCAGCA-3' & Alm et al. (1996) \\
GV-841 & Vibrio & 5'-AGGCCACAACCTCCAAGTAG-3' & Eilers et al. (2000) \\
\hline
\end{tabular}

dried and stored at $-20^{\circ} \mathrm{C}$ until the analysis in the laboratory. FISH hybridization was performed according to Glöckner et al. (1996) and Walczak and Brzezinska (2010). Prior to hybridization, the thawed filters were cut into small sections. The filter sections were placed on glass slides and covered with $20 \mu \mathrm{l}$ of a hybridization solution containing $0.9 \mathrm{M} \mathrm{NaCl}$, $20 \mathrm{mM}$ Tris- $\mathrm{HCl}$ ( $\mathrm{pH} 7.4$ ), $0.01 \%$ sodium dodecyl sulfate (SDS), variable (0-35\%) formamide concentrations and 50 ng of CY-3-labeled oligonucleotide. Hybridizations were carried out at $46^{\circ} \mathrm{C}$ for $2 \mathrm{~h}$ in an equilibrated sealed moisture chamber. After hybridization, the filters were transferred to a wash solution containing $20 \mathrm{mM}$ Tris $\mathrm{HCl}$ (pH 7.4), $5 \mathrm{mM}$ EDTA, $0.01 \% 10 \%$ SDS and a recommended concentration of $\mathrm{NaCl}$ determined by formamide concentration from a hybridization buffer. After hybridization, cells were stained with sterile $50 \mu \mathrm{g}$ of DAPI (4,6-diamidino-2-phenyl-indol) (Fluka) per $\mathrm{cm}^{3}$ for $15 \mathrm{~min}$ in the dark, then rinsed with $70 \%$ ethanol and air-dried on Whatman 3M paper. The filters were placed on a glass slide, and mounted with a 4:1 mix of Citifluor to minimize bleaching. Hybridized and DAPI stained cells were counted using an OLYMPUS BX-41 epifluorescence microscope equipped with a camera (Color View III) and fitted with a CY-3 filter (Omega optic Inc) and DAPI filter (UV 2A) at a magnification of 1000x. In all cases, bacteria were counted in 20 different fields with a minimum of 200 cells. The abundance per $1 \mathrm{dm}^{3}$ of water was calculated according to the formula proposed by Zimmermann and Meyer-Reil
(1974). Enumeration results were always corrected by subtracting signals observed with the nonsense probe NON338. According to Fuhrman and Azam (1982), bacterial counts are converted to bacteria biomass using the converting factor of $1.2 \cdot 10^{-10} \cdot \mathrm{dm}^{-3}$.

\section{Statistical analysis}

The standard deviation (SD), coefficient of variation (CV), and coefficient of dispersion (CD) were determined according to Velji and Albright (1986). The correlation between the levels of the studied bacteriological parameters was assessed with the Spearman rank order test. The significance of differences in bacteriological parameters among the seasons and sites was assessed by a two-way ANOVA and KruskalWallis tests according to Incera et al. (2003). In order to group the analyzed parameters according to their specific properties, the cluster analysis (the Ward method) and Euclidean distance were applied according to StatSoft Inc.

\section{Results}

The total number of bacteria (TBN) in the sediment-water interface of the marine harbour channel varied from 3.3 to 23.5 cells $10^{8} \cdot \mathrm{dm}^{-3}$ (average 7.4 cells $10^{8} \cdot \mathrm{dm}^{-3}$ ), while their biomass ranged from 39.4 to $282.4 \mu \mathrm{g} \mathrm{C} \cdot \mathrm{dm}^{-3}$ (average $89.3 \mu \mathrm{g}$ $\mathrm{C} \cdot \mathrm{dm}^{-3}$ ) during the annual cycle (Table 3 ). Phylogenetic analysis of the bacterial community showed that among five studied taxonomic bacterial groups the dominant ones throughout

Table 3. Total number and biomass bacteria and abundance phylogenetic groups bacteria in studied marine channel $*-\mu \mathrm{g} \cdot \mathrm{dm}^{-3}$

\begin{tabular}{lccccc}
\hline \hline \multirow{2}{*}{ Specificity } & \multicolumn{4}{c}{ Statistical parameters } \\
\cline { 2 - 6 } & Mean $\left(10^{8}\right.$ cells $\left.\cdot \mathrm{dm}^{-3}\right)$ & Range $\left(10^{8}\right.$ cells· $\left.\mathrm{dm}^{-3}\right)$ & SD & CV $[\%]$ & CD \\
\hline Total bacteria number (TBN) & 7.4 & $3.3-23.5$ & 5.0 & 67.0 & 354.1 \\
Bacterial biomass* & 89.3 & $39.4-282.4$ & 61.6 & 67.0 & 42.5 \\
Cytophaga-Flavobacterium (CF) & 1.1 & $0.4-2.4$ & 0.5 & 47.8 & 25.2 \\
Gammaproteobacteria (GMP) & 1.4 & $0.7-2.8$ & 0.5 & 39.8 & 21.4 \\
Marine alpha-cluster (MAC) & 0.9 & $0.3-1.8$ & 0.4 & 47.8 & 25.2 \\
Pseudomonas (P) & 0.4 & $0.2-0.7$ & 0.1 & 31.7 & 4.4 \\
Vibrio (V) & 0.4 & $0.05-0.7$ & 0.2 & 60.2 & 13.5 \\
\hline
\end{tabular}




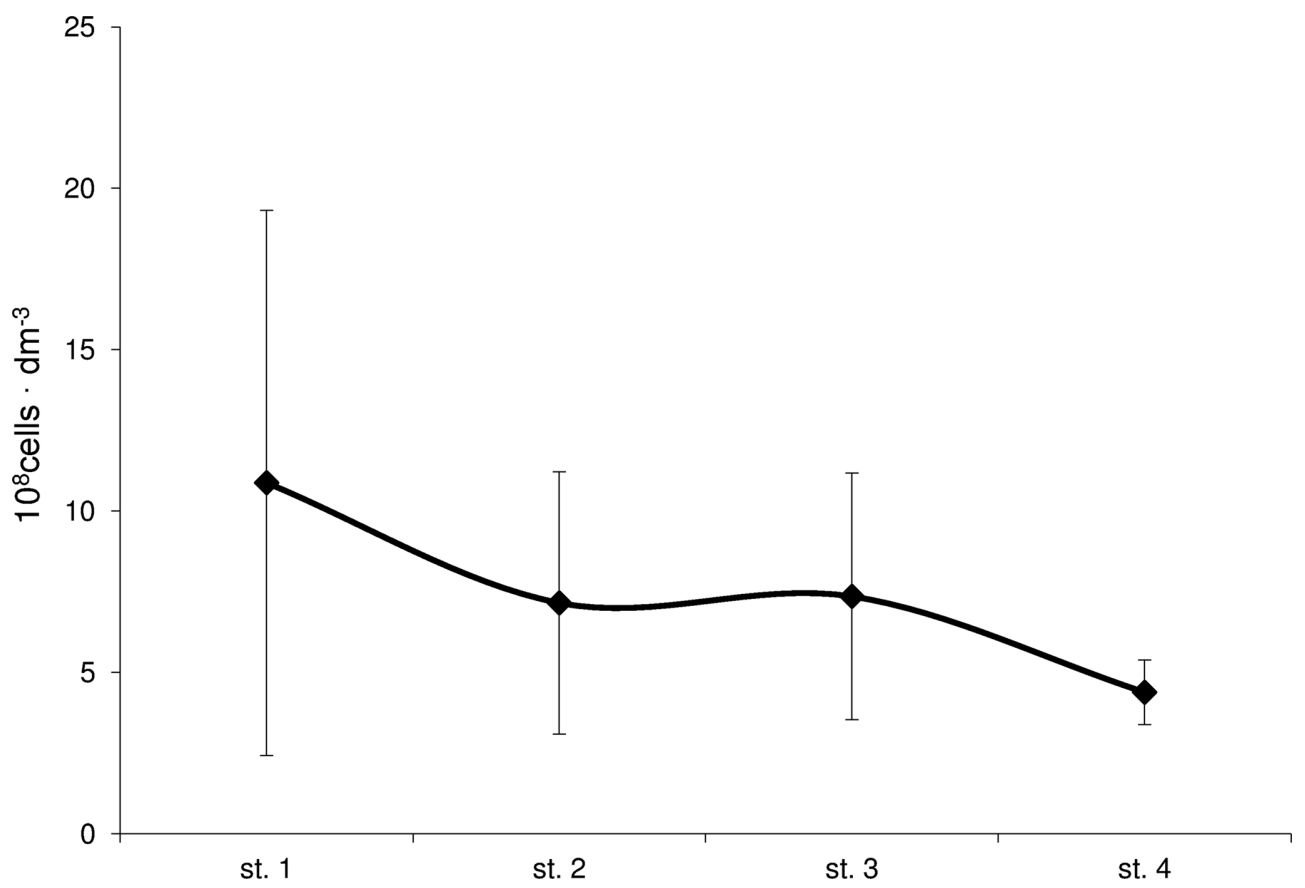

Fig. 3. Horizontal variations of total number of bacteria in sediment-water interface (average from the pooled data of all seasons). Vertical bars represent standard deviation, $\mathrm{n}=16$

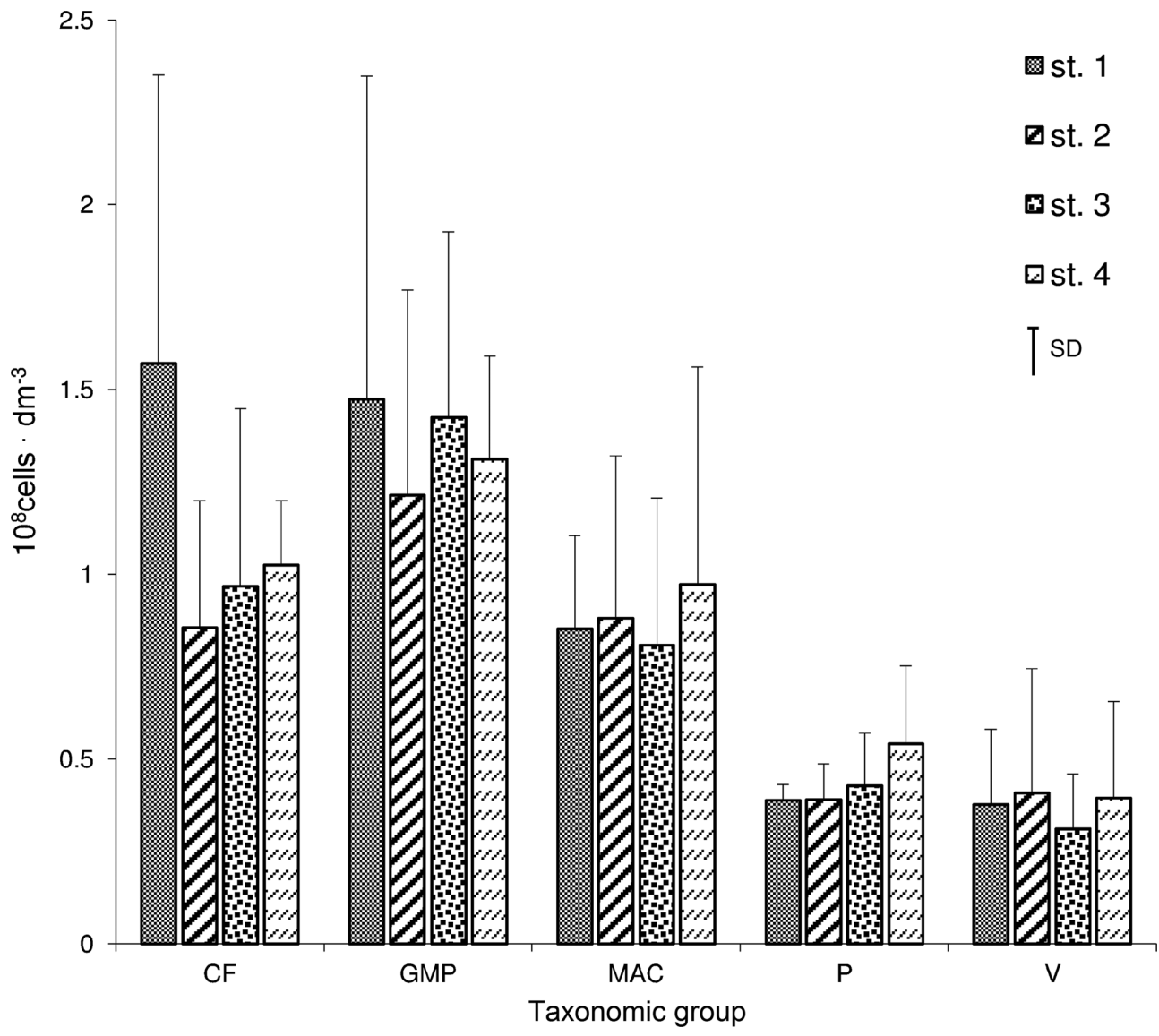

Fig. 4. Abundance studied taxonomic groups bacteria inhabiting sediment-water interface in horizontal profile harbour channel in Ustka (average from the pooled data of all seasons). Vertical bars indicate standard deviation, $n=16$ 
the year cycle were the Gammaproteobacteria subclass (1.4 cells $\left.10^{8} \cdot \mathrm{dm}^{-3}\right)$ and Cytophaga-Flavobacterium group (1.1 cells $\left.10^{8} \cdot \mathrm{dm}^{-3}\right)$. Vibrio and Pseudomonas represented only a small fraction $\left(0.4\right.$ cells $\left.10^{8} \cdot \mathrm{dm}^{-3}\right)$ of bacteria identified in the studied estuary (Table 3 ).
Data presented in Figure 3 show the differences in the total bacterial number along the spatial profile of the studied harbour channel. The maximum values $\left(10.8\right.$ cells $\left.10^{8} \cdot \mathrm{dm}^{-3}\right)$ of TBN in the sediment-water interface were noted at the site located on the border between the Shupia River and the channel
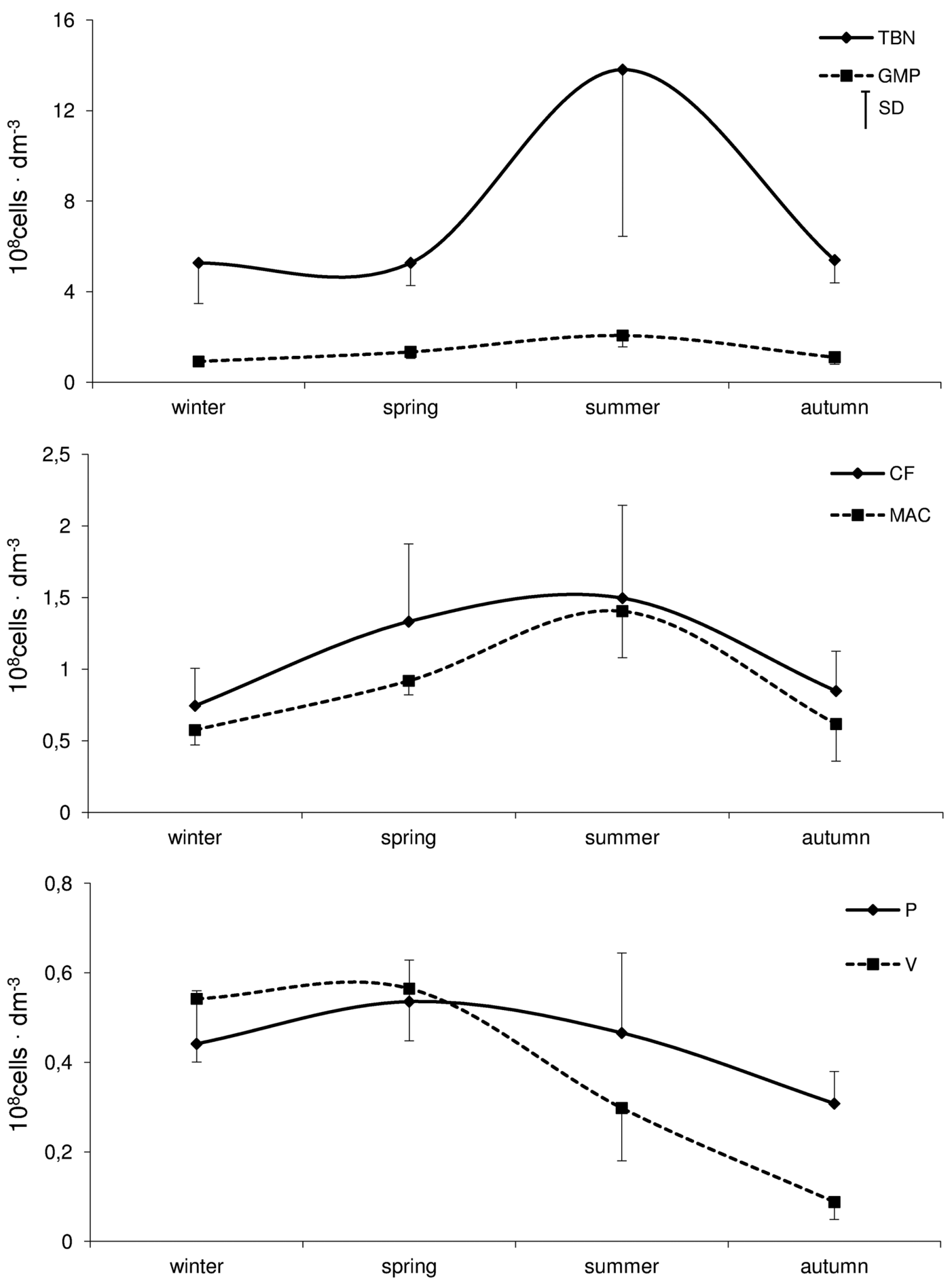

Fig. 5. Seasonal dynamics change of total bacteria number and taxonomic groups (average from the pooled data of four sites). Vertical bars indicate standard deviation, $\mathrm{n}=16$, Legends: TBN-Total number of bacteria; GMP-Gammaproteobacteria; CF-CytophagaFlavobacterium; MAC-Marine alpha-cluster; P-Pseudomona; V-Vibrio 
(freshwater zone-site 1 ). The lowest $\left(4.3\right.$ cells $10^{8} \cdot \mathrm{dm}^{-3}$ ) total numbers of bacteria in SWI were noted in the marine zone (site 4). The abundance of phylogenetic groups of bacteria in SWI along the horizontal profile of the studied channel is presented in Fig. 4. It is evident that besides CytophagaFlavobacterium, regarding which maximum values were recorded at site 1 , a very small fluctuation in the abundance of other taxonomic groups among the study sites of the marine harbor in Ustka was noted.

The results of our study showed that the total numbers of bacteria as well as the abundance of bacterial taxonomic groups were subject to seasonal fluctuation (Fig. 5). The highest total number of bacteria was recorded during summer. In other seasons, the number of these organisms was two-fold lower than in summer and remained at a similar level. Gammaproteobacteria, Cytophaga-Flavobacterium and Marine alpha-cluster were the most abundant in summer, while their number was lowest in winter. The number of the genera Pseudomonas peaked in spring and the highest number of the genera Vibrio was observed in winter and spring. The minimum number of both these groups was recorded in autumn.

The relationships between the polygenetic groups of bacteria in the sediment-water interface are given as a correlation matrix (Table 4). In SWI, we noted a significant positive correlation between the abundance of Flavobacterium-Cytophaga and Marine alpha-cluster $(\mathrm{r}=0.72)$ and Gammaproteobacteria $(\mathrm{r}=0.49)$. A significant positive correlation in the abundance of other groups of bacteria in this water layer was found between Marine alpha-cluster and Gammaproteobacteria $(\mathrm{r}=0.68)$ and also Pseudomonas $(\mathrm{r}=0.48)$ and between Pseudomonas and Vibrio $(\mathrm{r}=0.47)$.

By grouping the results by the seasons and sites the factorial Fisher and Kruskal -Wallis tests were carried out to detect significant differences between the total number of bacteria and abundance of five studied phylogenetic groups (Table 5). The abundance of Gammaproteobacteria, Marine alphacluster and Vibrio differed significantly between the studied seasons. In our study, there were no statistically significant differences in the abundance of the studied taxonomic groups among the study sites of the marine harbour channel in Ustka.

The results of a hierarchical dendrogram analysis of the studied taxonomic groups showed two distinct clusters (Fig. $6)$. The first cluster (1) comprised two taxonomic groups: Pseudomonas and Vibrio, while the second cluster(2) comprised Gammaproteobacteria, Marine alpha-cluster and FlavobacteriumCytophaga.

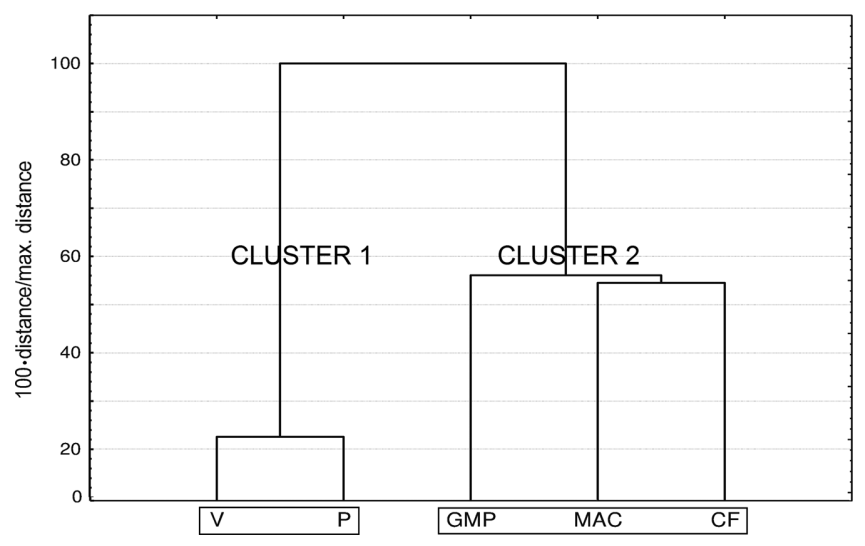

Fig. 6. Cluster analysis of particular enrichment factors performed for all studied phylogenetic groups bacteria (parameters applied: Euclidean distance, full binding)

Table 4. Correlation coefficient studied bacteriological parameters in sediment-water interface $(n=16)$, Significance level $(p)$ is indicated by asterisks $*^{*}$-value $<0.05, * *$ p-value $<0.01$

\begin{tabular}{lcccc}
\hline \hline & Cytophaga - flavobacterium & Gamma-proteobacteria Marine alfa cluster & Pseudomonas & Vibrio \\
\hline Cytophaga - flavobacterium & & & & \\
Gammaproteobacteria & $0.49^{*}$ & $0.68^{* *}$ & & \\
Marine alfa cluster & $0.72^{* *}$ & 0.08 & $0.48^{*}$ & $0.47^{*}$ \\
Pseudomonas & 0.19 & -0.05 & -0.01 & \\
Vibrio & 0.07 & &
\end{tabular}

Table 5. Analyses of 2-way-ANOVA and the Kruskal - Willis non-parametric test of variance in the studied taxonomic groups, due to site and season. Significance level ( $\mathrm{p})$ is indicated by asterisks $* * \mathrm{p}<0.01,{ }^{* *} \mathrm{p}<0.001$, ns-non-significant F-Fisher test, HKruskal-Wallis test

\begin{tabular}{|c|c|c|c|c|c|c|c|c|c|c|c|c|}
\hline \multirow{2}{*}{$\begin{array}{l}\text { Source of } \\
\text { variation }\end{array}$} & \multicolumn{2}{|c|}{ TBN } & \multicolumn{2}{|c|}{ Cytophaga-flavobacterium } & \multicolumn{2}{|c|}{ Gamma-proteobacteria } & \multicolumn{2}{|c|}{ Marine alfa cluster } & \multicolumn{2}{|c|}{ Pseudomonas } & \multicolumn{2}{|c|}{ Vibrio } \\
\hline & $\mathrm{H}$ & $\mathrm{p}$ & $\mathrm{H}$ & $\mathrm{p}$ & $\mathrm{F}$ & $\mathrm{p}$ & $\mathrm{F}$ & $\mathrm{p}$ & $\mathrm{F}$ & $\mathrm{p}$ & $\mathrm{F}$ & $\mathrm{p}$ \\
\hline Season & 4.79 & ns & 6.79 & ns & 9.06 & $* *$ & 12.16 & $* * *$ & 2.42 & ns & 16.59 & $* * *$ \\
\hline Site & 7.39 & ns & 2.02 & $\mathrm{~ns}$ & 0.15 & ns & 0.10 & ns & 1.09 & $\mathrm{~ns}$ & 0.12 & $\mathrm{~ns}$ \\
\hline
\end{tabular}




\section{Discussion}

In all aquatic ecosystems the basic parameters used to describe the structure of bacteriocenosis populations, besides the level of metabolic and respirometric activity, are the total bacterial number and their taxonomic diversity (Ivanov et al. 2013; Xia et al. 2014). The knowledge of bacterial taxonomic composition is important for the understanding of global and local patterns and the role that bacteria play in the overall processes in all water basins (Bowman and McCauig 2003; Liu et al. 2012).

The total number of bacteria inhabiting the sedimentwater interface in the marine harbour channel varied from 3.3 to $23.5 \cdot 10^{8}$ cells $\cdot \mathrm{dm}^{-3}$. This range was similar with those reported by Tholosan and Bianchi (1998) in the sedimentwater layer in NW Mediterranean $\left(5.5-29.2 \cdot 10^{8}\right.$ cells $\left.\cdot \mathrm{dm}^{-3}\right)$, in the eastern Kara Sea from the region of the Yenisei estuary $\left(1.7-2.5 \cdot 10^{7}\right.$ cells $\cdot \mathrm{dm}^{-3}$ ) (Ivanov et al. 2013), in Port Noarlunga in South Australia $\left(3.710^{5}-1.45 \cdot 10^{7} \cdot\right.$ cells $\cdot \mathrm{dm}^{-3}$ ) (Dann et al. 2014) and the harbour channel of the Buffalo River (2.7$\left.16.0 \cdot 10^{8} \mathrm{cells} \cdot \mathrm{dm}^{-3}\right)$ (Pettibone et al. 1996).

Phylogenetic diversity of bacterial community inhabiting the sediment-water interface in the marine harbor in Ustka showed that Gammaproteobacteria dominated among the studied taxonomic groups. This result corresponds to the results of earlier studies on the surface microlayer and subsurface water carried out by Perliński (2015) in this water basin. This taxonomic group is among three classes of the phylum Proteobacteria comprising gram-negative aerobic and anaerobic, and also chemoheterotrophic bacteria (Franklin et al. 2005; Hunter et al.2006). Gammaproteobacteria represent a large phylogenetic group of cosmopolitan species such as Colwellia, Alteromonas, Acinetobacter, Pseudoalteromonas, Shewnella, Marinobacter, Helomonas and Psychrobacter (Bowman and McCuaig 2003; Zhou et al. 2009). The dominance of this taxonomic group of bacteria in water basins has been reported by Cottrell and Kirchman (2000), Simanato et al. (2010) in water and by Xia et al. (2014), Galand et al. (2016) in sediment. A large number of Gammaproteobacteria in the sediment-water interface in the channel in Ustka most probably is due to the fact that those bacteria as a group are involved in many biodegradation processes, suggesting their importance in organic matter decomposition in SWI (Tanase et al. 2009; Zeng et al. 2011). Many bacteria from this taxonomic subclass have particular gene generating high proteolytic activity (Zhou et al. 2009; Alonso et al.
2010). In the sediment-water interface of the studied marine harbour channel, protein concentration $\left(15.4-31.9 \mu \mathrm{g} \cdot \mathrm{dm}^{-3}\right)$ and percentage of proteolytic bacteria (37-55\%) were high (Perliński 2015) and, consequently, that might induce the high abundance of Gammaproteobacteria observed in our study.

Apart from Gammaproteobacteria, the CytophagaFlavobacterium group was also an abundant phylogenetic group inhabiting the sediment-water interface of the studied water basin. Members of this taxonomic group are found in large numbers in all marine and freshwater basins (Feng et al. 2009; Liu et al. 2012). The genome analysis of Flavobacteria isolates has identified high numbers of genes encoding the synthesis of extracellular hydrolytic enzymes (Xu et al. 2003; Taylor et al. 2014). This suggests that this bacterial assemblage plays an important role in biochemical aerobic degradation processes of complex polymeric organic matter in water ecosystems (Tanase et al. 2009; Walczak and Brzezinska 2010; Liu et al. 2012). For this reason, the CytophagaFlavobacterium group has been characterized as metabolically highly active and able to degrade many high molecular weight compounds, mainly proteins, carbohydrates and lipids (Hempel et al. 2008), which were recorded in high concentrations in the sediment-water interface of the studied channel (Table 1).

Bacteria of Marine alpha-cluster group were comparatively less abundant in the sediment-water interface. Several studies (Sorokin 1995; Bowman et al. 1997; González et al. 1997) have shown that this taxonomic group comprises marine bacteria. Taking this fact into account, it seems reasonable that the maximum abundance of this bacterial group in the studied harbour channel was recorded in its most saline part (site 4). Similar results were reported by González and Moran (1997) in the estuary of the Altamaha River on the eastern coast of the United States.

Similar to the surface microlayer and subsurface water (Perliński 2015) of the studied harbour, the genera Vibrio and Pseudomonas represented only a small fraction of organisms in the sediment-water interface. Our results correspond to the findings on bacterial taxonomic composition in the Takayama River (Kenzaka et al. 1998), in the Changjiang Estuary and the coastal area of the East China Sea (Feng et al. 2009) and the surface sediment of the Yellow River China (Xia et al. 2014). The small number of the genera Vibrio and Pseudomonas in freshwater and brackish sediment-water interface in the studied marine harbour channel is probably due to the fact that these bacteria are typical marine organisms, which 
require salt for growth and metabolic activity (Langenheder et al. 2003; Riemann et al. 2008).

The results of our study indicated different TBN in the sediment-water interface along the horizontal profile of the marine harbor. The total number of bacteria inhabiting the studied layer was the highest in the freshwater zone (site 1) while the lowest was in the marine zone (site 4). This variation in the abundance of bacteria along the spatial profile of the channel in Ustka may be the result of changes in water salinity. According to Jiang et al. (2006) and Kouridaki et al. (2010), salinity, as a physiological stress factor, decreases cell-specific activity and growth efficiency and thus controls bacterial abundance. Alonso et al. (2010) and Lefort and Gasol (2013) observed a gradient of decreasing bacterial numbers with increasing salinity in water basins and this fact corresponds well with our results. Also, the estuarine character of the studied water basin that influences its hydrodynamics with steep physicochemical gradients due to the variability of freshwater and seawater input may impact on the total bacterial number along the horizontal profile (Webster et al. 2015; Wei et al. 2016).

Heidelberg et al. (2002) and Jorquera et al. (2004) reported the horizontal profile variation in the quantification of different bacterial taxonomic groups among marine and estuarine environments. According to Leford and Gasol (2013) and Galand et al. (2016), spatial variation in the bacterial composition and diversity is determined mainly by origin, concentration, availability and degradability of organic matter, as well as the level of metabolic activity of microbial populations. In our study, we did not find any considerable variation in the abundance and diversity of taxonomic groups among the study sites in SWI of the marine harbour channel in Ustka. These results may suggest lack of differences in organic matter concentrations and their availability and also similar levels of metabolic activity of bacteria along the horizontal profile of the studied harbour.

Our research documented seasonal fluctuation in the total number of bacteria in the studied water basin. The highest total number of bacteria was noted in the summer season. According to Mary et al. (2006) and Takenaka et al. (2007), the main stimulus for cell-specific activity, growth efficiency and multiplication of bacteria in summer is the intensive development of phytoplankton and phytobenthos. The assimilates released by these organisms are immediately used by bacteria as food or an energy substrate which generates an increase in their number. According to Cottrell and
Kirchman (2000) and Takenaka et al. (2007), relatively high temperatures in summer are also an important environmental factor directly governing bacterial activity and resulting in their high abundance. Seasonal variation in the number of determined bacterial polygenetic groups in the sedimentwater interface of the studied harbour channel was also shown by the results of the present study. This seasonal fluctuation in the number of bacterial taxonomic groups was earlier documented in the Delaware drainage basin (Hullar et al. 2006), Liu et al. (2012), in the Changjiang Estuary and East China Sea and in the Arabian Sea (Bandekar et al. 2016). Mary et al. (2006) and Bucci et al. (2014) suggested that a variety of different environmental parameters (temperature, nutrient concentration, liability of organic matter, primary production and grazing bacteria) favoured different groups of polygenetic bacteria at different times of the year. Gammaproteobacteria, Flavobacterium-Cytophaga and Marine alpha-cluster were dominant in the water of the studied water basin in summer. These results correspond to the results of earlier studies in the surface microlayer and subsurface water carried out by Perliński (2015) in this water basin and data collected in the Elbe and Spittelwasser rivers (Brümmer et al. 2000) and in the northern Baltic Sea Pinhassi and Hagström (2000).

\section{Conclusions}

In conclusion, we hope that our study will enhance knowledge about the spatial and seasonal polygenetic diversity of bacteria inhabiting the sediment-water interface in marine harbour channels.

\section{Acknowledgements}

We would like to thank the technical staff (Mr. Krzysztof Woźniak) of the Experimental Biology Department for help with laboratory work.

\section{Open Access}

This article is distributed under the terms of the Creative Commons Attribution 4.0 International License (http:// creativecommons.org/licenses/by/4.0/), which permits unrestricted use, distribution, and reproduction in any medium, provided you give appropriate credit to the original author(s) and the source, provide a link to the Creative Commons license, and indicate if changes were made. 


\section{References}

Accornero A, Picon P, de Bovée F (2002) Biogeochemical transformations of dissolved organic matter at the sedimentwater interface: results from in situ incubations within benthic chambers. Oceanol Acta 25:171-178

Alm EW, Oerther DB, Larsen N, Sthal D, Raslin L (1996) The oligonucleotide probe database. Appl Environ Microb 62: 3557-3559

Alonso C, Gomez-Pereria P, Ramette A, Ortega L, Fusch BM, Amann R (2010) Multilevel analysis of the bacterial diversity along the environmental gradient Rio de la Plata-South Atlantic Ocean. Aquat Microb Ecol 61:57-72

Amman RL, KrumholzL, Sthal DA (1990) Fluorescent oligonucleotide probing of whole cells for determinative phylogenetic and environmental studies in microbiology. J Bacteriol 172:762770

Bhaskar PV, Bhosle NB (2008) Bacterial production, glucosidase activity and particle-associated carbohydrates in Dona Paula bay, west coast of India. Estuar Coast Shelf S 80(3):413-424

Bowman JP, McCammon SA, Brown MV, Nichols DS, McMeekin TA (1997) Diversity and association of psychrophilic bacteria in Antarctic sea ice. Appl Environ Microb 63(8):3068-3078

Bowman JP, McCuaig RD (2003) Biodiversity, community structural shift, and biogeography of prokaryotes within Antarctic Continental shelf sediment. Appl Environ Microb 69(5):24632483

Brümmer IHM, Fehr W, Wagner-Döbler I (2000) Biofilm community structure in polluted rivers: abundance of dominant phylogenetic groups over a complete annual cycle. Appl Environ Microb 66(7):3078-3082

Bucci JP, Szempruch AJ, Caldwell JM, Ellis JC, Levine JF (2014) Seasonal changes in microbial community structure in freshwater stream sediment in a North Carolina river Basin. Diveristy 6(1):18-32. doi:10.3390/d6010018

Chai B, Huang T, Zhao X (2016) Microbial effect on nitrogen circulation and transformation on water-sediment interface of source water reservoir. Chem Engineer Trans 51:109-114

Christian BW, Lind OT (2007) Increased sediment-water interface bacterial $\left[{ }^{3} \mathrm{H}\right]$-L-serine uptake and biomass production in eutrophic reservoir during summer stratification. Fund Appl Limnol 168(2):189-199

Christowa Cz, Luks K, Christowa-Dobrowolska M, Szulc M, Kiełb-Stańczuk M, Podruczna B, Kasperek S, Hącia E (2007) The development strategy of the sea port in Ustka by 2021. Business Mobility International Private Limited Company, Słupsk

Cottrell MT, Kirchman DL (2000) Natural assemblages of marine Proteobacteria and members of the Cytophaga-Flavobacter cluster consuming low- and high- molecular-weight dissolved organic matter. Appl Environ Microb 66(4):1692-1697
Dann LM, Mitchell JG, Speck PG, Newton K, Jeffires T, Peterson $\mathrm{J}$ (2014) Virio-and bacterioplankton microscale distributions at the sediment-water interface. PLoS One 9:1-14

Daumas R (1990) Contribution of the water-sediment interface to the transformation of biogenic substances: application to nitrogen compounds. Hydrobiologia 207(1):15-29

Divya B, Kavungal SV, Nair S (2010) 16sRNA and enzymatic diversity of culturable bacteria from the sediments of oxygen minimum zone in the Arabian Sea. A Van Leeuw J Microb 98(1): $9-18$

Eilers T, Pernthaler J, Amann R (2000) Succcession of pelagic marine bacteria during enrichment a close look at cultivationinducted shifts. Appl Environ Microb 66:4634-4640

Eilers T, Schwarz G, Brinkmann H, Witt C, Richter T, Nieder J, Koch B, Hille R, Hänsch R, Mendel RR (2001) Identification and biochemical characterization of Arabidopsis thaliana sulfite oxidase. A new player in plant sulfur metabolism. J Biol Chem 276:46989-46994

Feng BW, Li XR, Wang JH, Hu ZY, Meng H, Xiang LY, Quan ZX (2009) Bacterial diversity of water and sediment in the Changjiang estuary and coastal area of the East China Sea. FEMS Microbiol Ecol 70(2):236-248

Franklin MP, McDonald IR, Bourne DG, Owens JP, Upstill-Goddard RC, Murrell JC (2005) Bacterial diversity in the bacterioneuston (sea surface microlayer): the bacterioneuston through the looking glass. Environ Microbiol 7(5):723-736

Fuhrman JA, Azam F (1982) Thymidine incorporation as a measure of heterotrophic bakterioplankton production in marine surface waters: evaluation and field results. Mar Biol 66(2):109-120

Galand PE, Lucas S, Fagervold SK, Peru E, Pruski AM, Vétion G, Dupuy Ch, Guizien K (2016) Disturbance increases microbial community diversity and production in marine sediments. Front Microbiol 7:1950. doi:10.3389/fmicb.2016.01950

Glöckner FO, Amann R, Alfreider A, Pernthaler J, Psenner R, Trebesius K, Schleifer KH (1996) An in situ hybridization protocol for detection and identification of planktonic bacteria. Syst Appl Microbiol 19(3):403-406

González JM, Mayer F, Moran MA, Hodson RE, Whitman WB (1997) Sagittula stellata gen. nov., sp. nov., a lignin-transforming bacterium from a coastal environment. Int J Syst Bacteriol 47(3):773-780

González JM, Moran MA (1997) Numerical dominance of a group of marine bacteria in the $\alpha$-subclass of the class Proteobacteria in coastal seawater. Appl Environ Microb 63(11):4237-4242

Heidelberg JF, Heidelberg KB, Colwell RR (2002) Bacteria of the gamma-subclass Proteobacteria associated with zooplankton in Chesapeake Bay. Appl Environ Microb 68:5498-5507

Hempel M, Blume M, Blindow I, Gross EM (2008). Epiphytic bacterial community composition on two common submerged macrophytes in brackish water and freshwater. BMC Microbiol 8:58. doi:10.1186/1471-2180-8-58 
Hervas A, Casamayor EO(2008) High similarity between bacterioneuston and airborne bacterial community compositions in a high mountain lake area. FEMS Microbiol Ecol 67(2):219-228

Hullar MA, Kaplan LA, Stahl A (2006) Recurring seasonal dynamics of microbial communities in stream habitats. Appl Environ Microb 72(1):713-722

Hunter EM, Mills HJ, Kostka JE (2006) Microbial community diversity associated with carbon and nitrogen cycling in permeable shelf sediments. Appl Environ Microb 72(9):5689-5701

Incera M, Cividanes SP, López J, Costas R (2003) Role of hydrodynamic conditions on quantity and biochemical composition of sediment organic matter in sandy intertidal sediments (NW Atlantic coast, Iberian Peninsula). Hydrobiologia 497(1):39-51

Ivanov MV, Lein AYu, Savvichev AS, Rusanov II, Veslopolova EF, Zakharova EE, Prusakova TS (2013) Abundance and activity of microorganisms at the water-sediment interface and their effect on the carbon isotopic composition of suspended organic matter and sediments of the Kara Sea. Microbiology 82(6):735742

Jiang H, Dong H, Zhang G, Yu B, Chapman LR, Fields MW (2006) Microbial diversity in water and sediment of lake Chaka, an Athalassohaline lake in Northwestern China. Appl Environ Microb 72(6):3832-3845

Jorquera MA, Lody M, Leyton Y, Riquelme C (2004) Bacteria of subclass $\gamma$-Proteobacteria associated with commercial Argopecten purpuratus (Lamark, 1819) hatcheries in Chile. Aquaculture 236(1-4):37-51

Kenzaka T, Yamaguchi N, Tani K, Nasu M (1998) rRNA-targeted fluorescent in situ hybridization analysis of bacterial community structure in river water. Microbiology 144(8):2085-2093

Kouridaki I, Polymenakou PN, Tselepides A, Mandalakis M, Smith KL Jr (2010) Phylogenetic diversity of sediment bacteria from the deep Northeastern Pacific Ocean: a comparison with the deep Eastern Mediterranean Sea. Int Microbiol 13(3):143150

Langenheder S, Kisand V, Wikner J, Tranvik LJ (2003) Salinity as a structuring factor for the composition and performance of bacterioplankton degrading riverine DOC. FEMS Microbiol Ecol 45(2):189-202

Lefort T, Gasol JM (2013) Global-scale distributions of marine surface bacterioplankton groups along gradients of salinity, temperature, and chlorophyll: a meta-analysis of fluorescence in situ hybridization studies. Aquat Microb Ecol 70(2):111-130

Liu M, Xiao T, Wu Y, Zhou F, Huang H, Bao S, Zhang W (2012) Temporal distribution of bacterial community structure In the Changjiang estuary hypoxia area and the adjacent East China Sea. Environ Res Lett 7:11. doi:10.1088/1748-9326/7/2/025001

Manz WR, Amann W, Ludwig W, Wagner M, Schleifer KH (1992) Pylogenetic oligonucleotide probes for the major subclasses of proteobacteria problems and solutions. Syst Appl Microbiol 15:593-600
Manz W, Amann R, Ludwig W, Vancanneyt M, Schleifer KH (1996) Application of a suite of 16S rRNA-specific oligonucleotide probes designed to investigate bacteria of the phylum cytophagaflavobacter-bacteroides in the natural environment. Microbiology 142:1097-1106

Mary I, Cummings DG, Biegala IC, Burkill PH, Archer SD, Zubkov MV (2006) Seasonal dynamics of bacterioplankton community structure at a coastal station in the western English Channel. Aquat Microb Ecol 42(2):119-126

Perliński P (2015) Microbiological study of air-water and sedimentwater interface in harbour channel in Ustka. Ph.D. Thesis, Pomeranian University in Słupsk, $128 \mathrm{p}$

Pettibone GW, Irvine KN, Monahan KM (1996) Impact of a ship passage on bacteria levels and suspended sediment characteristics in the Buffalo river, New York. Water Res 30:2517-2521

Pinhassi J, Hagström A (2000) Seasonal succession in marine bacterioplankton. Aquat Microb Ecol 21:245-256

Queiroz RL, Brandini FP, Pellizzari FM (2004) Dynamic of microalgal communities in the water-column/sediment interface of the inner shelf off parana state, southern Brazil. Braz J Oceanogr 52(3-4):183-194

Riemann L, Leitet C, Pommier T, Simu K, Holmfeldt K, Larsson U, Hagström A (2008) The native bacterioplankton community in the Central Baltic Sea Is influenced by freshwater bacterial species. Appl Environ Microb 74(2):503-515

Santschi P, Höhener P, Benoti G, Buchholtz-ten Brink M (1990) Chemical processes at the sediment-water interface. Mar Chem 30:269-315

Simanato F, Gomez-Pereira PR, Fusch BM, Amann R (2010) Bacterioplankton diversity and community composition in the Southern Lagoon Venice. Syst Appl Microbiol 33(3):128-138

Snelgrove PVR, Austen MC, Boucher G, Heip C, Hutchings PA, King GM, Koike I, Lambshead PJD, Smith CR (2000) Linking biodiversity above and below the marine sediment-water interface. Bioscience 50(12):1076-1088

Sorokin DY (1995) Sulfitobacter pontiacus gen. nov., sp. nov.: a new heterotrophic bacterium from the Black Sea, specialized on sulfite oxidation. Microbiology 64:354-365

Stolle Ch, Labrenz M, Meeske Ch, Jürgens K (2011) Bacterioneuston community structure in the Southern Baltic Sea and its dependence on meteorological conditions. Appl Environ Microb 77(11):3726-3733

Takenaka T, Tashiro T, Ozaki A, Kato K (2007) Planktonic bacterial population dynamics and environmental changes in coastal areas of Suruga Bay. Microbes Environ 22(3):257-267

Tanase AM, Vassu T, Trasca C, Stoica I (2009) In situ visualization of natural microbial communities in Black Sea coastal shelf sediments. Rom Biotech Lett 14(1):4187-4193

Taylor JD, Cottinham SD, Billinge J, Cunliffe M (2014) Seasonal microbial community dynamics correlate with phytoplanktonderived polysaccharides ii surface coastal waters. ISME J 


\section{8:245-248}

Tholosan O, Bianchi A (1998) Bacterial distribution and activity at the water-sediment boundary layer on NW Mediterranean continental margin. Mar Ecol-Prog Ser 168:273-283

Velji MJ, Albright J (1986) Microscopic enumeration of attached marine bacteria of seawater, marine sediment, fecal matter and kelp blade samples following pyrophosphate and ultrasound treatments. Can J Microbiol 32(2):121-126

Viaroli P, Bartoli M, Giordani G, Magni P, Welsh DT (2004) Biochemical indicators as tools for assessing sediment quality/ vulnerability in transitional aquatic ecosystems. Aquat Conserv 14:S19-S29

Walczak M, Brzezinska SM (2010) Phylogenetic diversity and abundance of bacteria from surface microlayer and subsurface water in eutrophic Lake. Pol J Ecol 58(1):177-186

Webster G, O'Sullivan LA, Meng Y, Williams AS, Sass AM, Watkins AJ, Parkes RJ, Weightman AJ (2015) Archeal community diversity and abundance changes along a natural salinity gradient in estuarine sediments. FEMS Microbiol Ecol 91(2):1-18

Wei G, Li M, Li F, Li H, Gao Z (2016) Distinct distribution patterns of prokaryotes between sediment and water In the Yellow River estuary. Appl Microbiol Biot 100(22):9683-9697

Wu F, Qing H, Wan G (2001) Regeneration of N, P and Si near the sediment-water interface of lakes from southwestern China plateau. Water Res 35(5):1334-1337

Xia N, Xia X, Liu T, Hu L, Zhu B, Zhang X, Dong J (2014)
Characteristics of bacterial community In the water and surface sediment of the Yellow River, China, the largest turbid river in the world. J Soil Sediment 14(11):1894-1904

Xu JMK, Bjursell J, Himrod S, Deng LK, Carmichael HC, Ching LY, Hopper L, Gordon JJ (2003) A genomic view of the human Bacterioides thetaiotomicron symbiosis. Science 299(5615):2074-2076

Zeng Y, Zou Y, Chen B, Grebmeier JM, Li H, Yu Y, Zheng T (2011) Phylogenetic diversity of sediment bacteria in the northern Bering Sea. Polar Biol 34(6):907-919

Zhou MY, Chen XL, Zhao HL, Dang HY, Luan XW, Zhang XY, He HL, Zhou BC, Zhang YZ (2009) Diversity of both the cultivable protease-producing bacteria and their extracellular proteases in the sediments of the South China Sea. Microb Ecol 58(3):582-590

Zhu Y, Wu F, Feng W, Liu S, Giesy JP (2016) Interaction of alkaline phosphatase with minerals and sediments: activities, kinetics and hydrolysis of organic phosphorus. Colloid Surface A 495:46-53

Zimmermann R, Meyer-Reil A (1974) A new method for fluorescence staining of bacterial populations an membrane filters. Kiel Meeresforsch 30:24-27

Publisher's Note Springer Nature remains neutral with regard to jurisdictional claims in published maps and institutional affiliations. 